Article

\title{
Compounds from the Roots and Rhizomes of Valeriana amurensis Protect against Neurotoxicity in PC12 Cells
}

\author{
Qiuhong Wang ${ }^{1, \dagger}$, Changfu Wang ${ }^{1, \dagger}$, Yueming Zuo ${ }^{2}$, Zhibin Wang ${ }^{1}$, Bingyou Yang ${ }^{1}$ and \\ Haixue Kuang ${ }^{1, *}$
}

1 Key Laboratory of Chinese Materia Medica (Ministry of Education), Heilongjiang University of Chinese Medicine, No. 24 HePing Road, XiangFang District, Harbin 150040, China;

E-Mails: qhwang668@sina.com (Q.W.); wangchangfu831124@163.com (C.W.); wzbmailbox@126.com (Z.W.); ybywater@163.com (B.Y.)

2 Jiangxi University of Traditional Chinese Medicine, Nanchang 330006, China;

E-Mail: zuo_yueming@163.com

$\dagger$ These authors contributed equally to this work.

* Author to whom correspondence should be addressed; E-Mail: hxkuang@hotmail.com;

Tel.: +86-451-8219-3001; Fax: +86-451-8211-0803.

Received: 12 November 2012; in revised form: 6 December 2012 / Accepted: 11 December 2012 / Published: 18 December 2012

\begin{abstract}
Three new germacrane-type sesquiterpenoids, heishuixiecaoline A-C (compounds 1-3), were isolated along with ten known compounds 4-13 from fraction of Valeriana amurensis roots and rhizomes effective against Alzheimer's disease (AD). The structures of 1-3 were elucidated on the basis of their spectroscopic data. We also investigated the protective effect of compounds 1-13 on the neurotoxicity of PC12 cells induced by amyloid-beta $\left(\mathrm{A} \beta_{25-25}\right)$, respectively. As a result, germacrane-type sesquiterpenoids 1-4 and lignans 5-7 were seen to afford protection against $A \beta$-induced toxicity in PC 12 cells. This study will contribute to revealing the chemical basis for the therapeutic effect of $V$. amurensis against AD.
\end{abstract}

Keywords: Valeriana amurensis; germacrane-type sesquiterpenoids; heishuixiecaoline; lignans; PC 12 cell 


\section{Introduction}

The genus Valeriana has been taxonomically placed in the family Valerianaceae, comprising ca. 30 species in China [1]. Valerian (Valerianacae) is a perennial herb and some species in this genus have been used widely as a mild sedative and sleep aid for centuries in Europe and North America [2-4]. Previous studies on genus Valeriana plants indicated anxiolytic, antidepressant, antispasmodic, sedative, antitumor, and anti-HIV activities [5-9]. As one species of Valeriana, Valeriana amurensis is abundantly distributed in northeast China, especially in the Great Xing'an Mountains area. However, there were no investigations about its pharmacology activity and chemical constituents except for the sedative and anti-hyperspasmia effects of $V$. amurensis volatile oil [10] until we reported its potential therapeutic effect in Alzheimer's disease (AD) for the first time [11,12]. We have also screened and determined the AD-effective fraction $(50 \% \mathrm{EtOH}$ fraction from $\mathrm{AB}-8$ macroporous resin column of $95 \% \mathrm{EtOH}$ extract) from the previous studies [11,12], based on which a bioassay-guided isolation and phytochemical study of $V$. amurensis was performed and three new and ten known compounds were obtained from the effective fraction. The structures of known compounds 4-13 were determined by detailed 1D- and 2D-NMR analyses, ESI-MS and comparison of their spectral data with literature values. In this paper, the isolation and structural elucidation of the new germacrane-type sesquiterpenoids $\mathbf{1}-\mathbf{3}$ is described. We also investigated the neuroprotective effects of compounds 1-15 in a PC12 neuronal cell line. The PC12 cell line, derived from rat pheochromocytoma, displays phenotypic characteristics of sympathetic neurons. The cells were grown in the presence of various toxins mimicking the conditions taking place in neurodegenerative diseases, including amyloid-beta (A $\beta$, the peptide composing the amyloid plaques in brains of $\mathrm{AD}$ patients).

\section{Results and Discussion}

Compound 1 was obtained as white amorphous powder, and assigned the molecular formula $\mathrm{C}_{17} \mathrm{H}_{24} \mathrm{O}_{3}$ from its HRESIMS $\left(\mathrm{m} / z 299.1619[\mathrm{M}+\mathrm{Na}]^{+}\right.$, calc. for $\left.\mathrm{C}_{17} \mathrm{H}_{24} \mathrm{O}_{3} \mathrm{Na}, 299.1623\right)$ and NMR data (Table 1). Six degrees of unsaturation can be concluded for $\mathbf{1}$ according to the molecular formula $\mathrm{C}_{17} \mathrm{H}_{24} \mathrm{O}_{3}$. The IR spectrum displayed the presence of carbonyl $\left(1736 \mathrm{~cm}^{-1}\right), \alpha, \beta$-unsaturated aldehyde $\left(1682 \mathrm{~cm}^{-1}\right)$, and double-bond $\left(1625 \mathrm{~cm}^{-1}\right)$ absorptions.

The ${ }^{1} \mathrm{H}-\mathrm{NMR}$ spectrum of compound 1 (Table 1) displayed four methyl singlets $\left[\delta_{\mathrm{H}} 1.18(\mathrm{H}-12)\right.$, $1.20(\mathrm{H}-13), 1.34(\mathrm{H}-15), 2.03(\mathrm{H}-17)]$, signals for two olefinic protons [ $\left.\delta_{\mathrm{H}} 5.31(\mathrm{H}-1), 6.57(\mathrm{H}-5)\right]$, and an oxygenated methine proton $\left[\delta_{\mathrm{H}} 4.50(\mathrm{H}-8)\right]$, and an aldehydic proton $\left[\delta_{\mathrm{H}} 9.30(\mathrm{H}-14)\right]$. Analysis of its ${ }^{13} \mathrm{C}$-NMR and DEPT spectra showed 17 carbon resonances, including four methyls, three methylenes, three methines (one oxygenated), two trisubstituted double bond $\left[\delta_{\mathrm{C}} 145.1\right.$ (C-4), $155.8(\mathrm{C}-5)$, 128.7(C-1), 133.7 (C-10)], a carbonyl carbon $\left[\delta_{\mathrm{C}} 172.1\right.$ (C-16)], and an aldehydic carbon $\left[\delta_{\mathrm{C}} 196.6\right.$ (C-14)]. The acetate group was determined to be located at $\mathrm{C}-8$ by the HMBC correlations from $\mathrm{H}-8$ $\left(\delta_{\mathrm{H}} 4.50\right)$ to $\mathrm{C}-16, \mathrm{C}-11\left(\delta_{\mathrm{C}} 23.7\right), \mathrm{C}-7\left(\delta_{\mathrm{C}} 40.8\right)$, and $\mathrm{C}-9\left(\delta_{\mathrm{C}} 47.2\right)$. The other correlations in the $\mathrm{HMBC}$ and ${ }^{1} \mathrm{H}-{ }^{1} \mathrm{H}-\mathrm{COSY}$ spectra as shown in Figure 1 confirmed the connectivities in compound $\mathbf{1}$. 
Table 1. The ${ }^{1} \mathrm{H}-\mathrm{NMR}$ data of $\mathbf{1}-\mathbf{3}$ in $\mathrm{CD}_{3} \mathrm{OD}$ ( $\delta$ in ppm, recorded at $400 \mathrm{MHz}$ ).

\begin{tabular}{cccc}
\hline No. & $\mathbf{1}$ & $\mathbf{2}$ & $\mathbf{3}$ \\
\hline 1 & $5.31(1 \mathrm{H}, \mathrm{dd}, 4.4,9.6)$ & $5.25(1 \mathrm{H}, \mathrm{dd}, 4.0,9.2)$ & $3.59(1 \mathrm{H}, \mathrm{dd}, 6.8,9.2)$ \\
$2 \mathrm{a}$ & $2.09(1 \mathrm{H}, \mathrm{m})$ & $2.04(1 \mathrm{H}, \mathrm{m})$ & $1.97(2 \mathrm{H}, \mathrm{m})$ \\
$2 \mathrm{~b}$ & $2.15(1 \mathrm{H}, \mathrm{m})$ & $2.11(1 \mathrm{H}, \mathrm{m})$ & \\
$3 \mathrm{a}$ & $2.09(1 \mathrm{H}, \mathrm{m})$ & $2.03(1 \mathrm{H}, \mathrm{m})$ & $1.78(1 \mathrm{H}, \mathrm{m})$ \\
$3 \mathrm{~b}$ & $2.69(1 \mathrm{H}, \mathrm{m})$ & $2.69(1 \mathrm{H}, \mathrm{dd}, 4.0,11.2)$ & $2.45(1 \mathrm{H}, \mathrm{m})$ \\
5 & $6.57(1 \mathrm{H}, \mathrm{d}, 9.8)$ & $6.56(1 \mathrm{H}, \mathrm{d}, 9.6)$ & $6.49(1 \mathrm{H}, \mathrm{d}, 6.8)$ \\
6 & $1.85(1 \mathrm{H}, \mathrm{t}, 9.8)$ & $1.73(1 \mathrm{H}, \mathrm{t}, 9.6)$ & $1.46(1 \mathrm{H}, \mathrm{dd}, 6.8,11.2)$ \\
7 & $1.41(1 \mathrm{H}, \mathrm{t}, 9.8,10.8)$ & $1.17(1 \mathrm{H}, \mathrm{t}, 10.8)$ & $0.86(1 \mathrm{H}, \mathrm{dt}, 2.4,12.4)$ \\
& & & $1.78(1 \mathrm{H}, \mathrm{ddd}, 4.0,4.0,14.4) ;$ \\
8 & $4.50(1 \mathrm{H}, \mathrm{dt}, 3.2,10.8)$ & $3.35(1 \mathrm{H}, \mathrm{dt}, 4.4,10.8)$ & $1.04(1 \mathrm{H}, \mathrm{m})$ \\
& & & $2.13(1 \mathrm{H}, \mathrm{dt}, 4.8,12.8) ;$ \\
& $2.20(1 \mathrm{H}, \mathrm{dd}, 2.8,11.2) ;$ & $2.23(2 \mathrm{H}, \mathrm{m})$ & $2.49(1 \mathrm{H}, \mathrm{m})$ \\
12 & $2.30(1 \mathrm{H}, \mathrm{t}, 11.2)$ & $1.19(3 \mathrm{H}, \mathrm{s})$ & $1.12(3 \mathrm{H}, \mathrm{s})$ \\
13 & $1.18(3 \mathrm{H}, \mathrm{s})$ & $1.34(3 \mathrm{H}, \mathrm{s})$ & $1.14(3 \mathrm{H}, \mathrm{s})$ \\
14 & $1.20(3 \mathrm{H}, \mathrm{s})$ & $9.24(1 \mathrm{H}, \mathrm{s})$ & $9.35(1 \mathrm{H}, \mathrm{s})$ \\
15 & $9.30(1 \mathrm{H}, \mathrm{s})$ & $1.28(3 \mathrm{H}, \mathrm{s})$ & $5.07(1 \mathrm{H}, \mathrm{brs}) ; 5.12(1 \mathrm{H}, \mathrm{brs})$ \\
17 & $1.34(3 \mathrm{H}, \mathrm{s})$ & -- & -- \\
\hline
\end{tabular}

Figure 1. Key ${ }^{1} \mathrm{H}-{ }^{1} \mathrm{H}$ COSY and HMBC correlations of compounds 1-3.

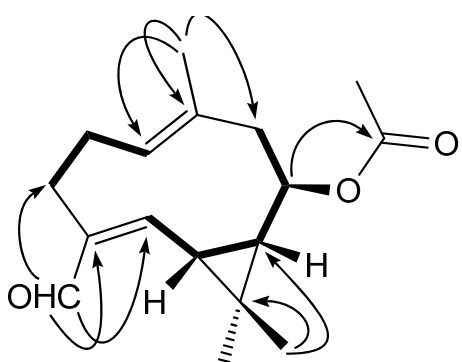

1

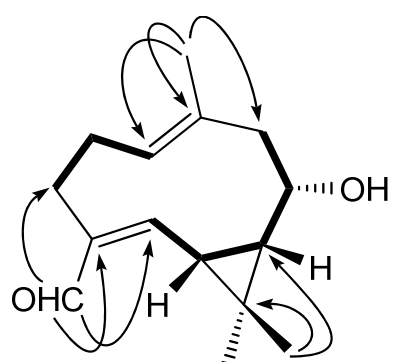

2

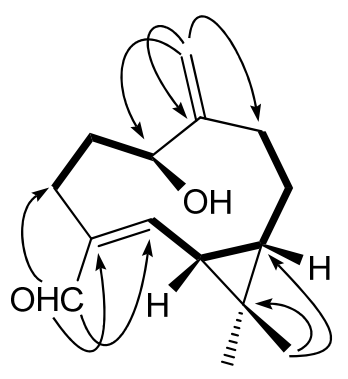

3

The relative configurations at C-6, C-7, and C-8 in $\mathbf{1}$ were deduced by a ROESY experiment (Figure 2) and ${ }^{1} \mathrm{H}-\mathrm{NMR}$ coupling constants [13].

Figure 2. Key ROESY correlations of compounds 1-3.
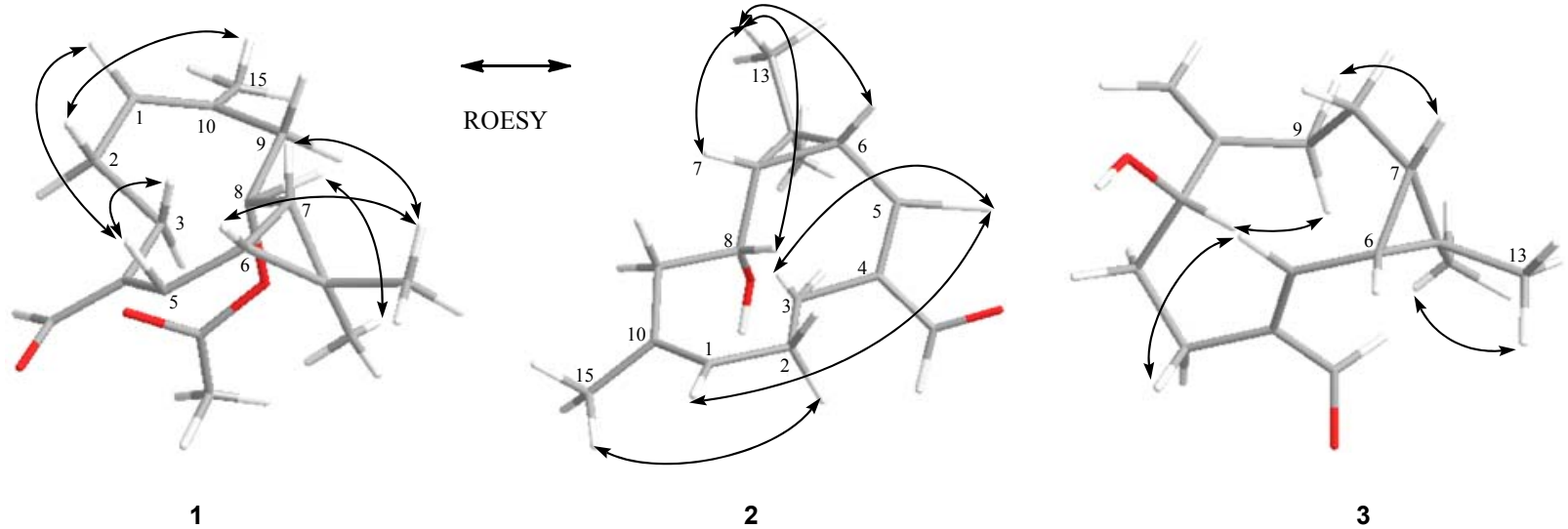
The coupling constant of $9.8 \mathrm{~Hz}$ and the NOE correlations between H-6 and H-7 suggested syn configuration of the cyclopropane moiety, the $\beta$-orientation of H-6 and H-7 were assigned by the correlations of $\mathrm{H}-7 / \mathrm{CH}_{3}-13$ and $\mathrm{H}-6 / \mathrm{CH}_{3}-13$. The $\alpha$-orientation of $\mathrm{H}-8$ was established by the correlations of $\mathrm{H}-8 / \mathrm{CH}_{3}-12$. The correlations of $\mathrm{H}-5 / \mathrm{H}-3 \mathrm{a}$ and $\mathrm{H}-2$ (a, b)/ $\mathrm{CH}_{3}-15$ indicated $\Delta^{4,5}$ and $\Delta^{1,10}$ to be $Z$ - and $E$-configured, respectively, which was confirmed by a key NOE correlation of H- 5 with H-1. Therefore, the structure of compound $\mathbf{1}$ was established as 10-methyl-6,7-dimethylmethylene- $8 \beta$-acetoxy-4-aldehyde-(4Z,10E)-dicyclodecadiene (Figure 3), and this compound was named heishuixiecaoline A.

Compound 2 was isolated as white amorphous powder, and its molecular formula was determined to be $\mathrm{C}_{15} \mathrm{H}_{22} \mathrm{O}_{2}$ by HRESIMS ( $\mathrm{m} / z$ 257.1514 [M+Na] $]^{+}$, calc. for $\left.\mathrm{C}_{15} \mathrm{H}_{22} \mathrm{O}_{2} \mathrm{Na}, 257.1517\right)$, requiring five degrees of unsaturation. The IR spectrum displayed the presence of hydroxyl $\left(3429 \mathrm{~cm}^{-1}\right), \alpha, \beta$-unsaturated aldehyde $\left(1689 \mathrm{~cm}^{-1}\right)$, and double-bond $\left(1624 \mathrm{~cm}^{-1}\right)$ absorptions. The ${ }^{1} \mathrm{H}$ - and ${ }^{13} \mathrm{C}$-NMR spectra data (Tables 1 and 2) of $\mathbf{2}$ were a little similar to those of $\mathbf{1}$, The differences found were the absence of the acetate group signals at $\delta_{\mathrm{C}} 172.1(\mathrm{C}-16)$ and $21.3(\mathrm{C}-17)$ in compound 2, other differences such as the NMR data in C-7, C-8, and C-9 suggested hydroxy group is linked to C-8 in compound 2 . The structure of 2 was further confirmed by the correlations of $\mathrm{HMBC}$ and ${ }^{1} \mathrm{H}-{ }^{1} \mathrm{H}$ COSY spectra as shown in Figure 1.

The relative configurations at C-6, C-7, and C-8 in $\mathbf{2}$ were deduced by a ROESY experiment (Figure 2). The syn configuration of $\mathrm{H}-7$ and H-6 were determined as described in compound $\mathbf{1}$, and the $\beta$-orientation of $\mathrm{H}-7$ and $\mathrm{H}-6$ were assigned by the correlations of $\mathrm{H}-7 / \mathrm{CH}_{3}-13$ and $\mathrm{H}-6 / \mathrm{CH}_{3}-13$. The $\beta$-orientation of $\mathrm{H}-8$ was established by the correlations of $\mathrm{H}-8 / \mathrm{CH}_{3}-13$, and the $Z$ - and $E$-configuration of $\Delta^{4,5}$ and $\Delta^{1,10}$ were determined same to 1 by the correlations $\mathrm{H}-5 / \mathrm{H}-3 \mathrm{a}, \mathrm{H}-2(\mathrm{a}, \mathrm{b}) / \mathrm{CH}_{3}-15$, and $\mathrm{H}-5 / \mathrm{H}-1$. Therefore, compound $\mathbf{2}$ was established as 10-methyl-6,7-dimethylmethylene-8 $\alpha$-hydroxy-4-aldehyde$(4 Z, 10 E)$ )-dicyclodecadiene (Figure 3), and this compound was named heishuixiecaoline B.

Table 2. The ${ }^{13} \mathrm{C}-\mathrm{NMR}$ and DEPT data of $\mathbf{1}-\mathbf{3}$ in $\mathrm{CD}_{3} \mathrm{OD}(\delta$ in ppm, recorded at $100 \mathrm{MHz})$.

\begin{tabular}{cccc}
\hline No. & $\mathbf{1}$ & $\mathbf{2}$ & $\mathbf{3}$ \\
\hline 1 & $128.7(\mathrm{CH})$ & $127.7(\mathrm{CH})$ & $68.5(\mathrm{CH})$ \\
2 & $28.3\left(\mathrm{CH}_{2}\right)$ & $28.3\left(\mathrm{CH}_{2}\right)$ & $30.1\left(\mathrm{CH}_{2}\right)$ \\
3 & $24.5\left(\mathrm{CH}_{2}\right)$ & $24.4\left(\mathrm{CH}_{2}\right)$ & $22.8\left(\mathrm{CH}_{2}\right)$ \\
4 & $145.1(\mathrm{C})$ & $144.1(\mathrm{C})$ & $146.3(\mathrm{C})$ \\
5 & $155.8(\mathrm{CH})$ & $157.4(\mathrm{CH})$ & $155.4(\mathrm{CH})$ \\
6 & $31.9(\mathrm{CH})$ & $32.1(\mathrm{CH})$ & $28.5(\mathrm{CH})$ \\
7 & $40.8(\mathrm{CH})$ & $44.1(\mathrm{CH})$ & $36.3(\mathrm{CH}))$ \\
8 & $73.6(\mathrm{CH})$ & $69.9(\mathrm{CH})$ & $23.2\left(\mathrm{CH}_{2}\right)$ \\
9 & $47.2\left(\mathrm{CH}_{2}\right)$ & $50.8\left(\mathrm{CH}_{2}\right)$ & $37.5\left(\mathrm{CH}_{2}\right)$ \\
10 & $133.7(\mathrm{C})$ & $134.6(\mathrm{C})$ & $149.0(\mathrm{C})$ \\
11 & $23.7(\mathrm{C})$ & $23.5(\mathrm{C})$ & $21.8(\mathrm{C})$ \\
12 & $28.3\left(\mathrm{CH}_{3}\right)$ & $28.7\left(\mathrm{CH}_{3}\right)$ & $28.1\left(\mathrm{CH}_{3}\right)$ \\
13 & $16.0\left(\mathrm{CH}_{3}\right)$ & $16.0\left(\mathrm{CH}_{3}\right)$ & $16.2\left(\mathrm{CH}_{3}\right)$ \\
14 & $196.6(\mathrm{CH})$ & $196.6(\mathrm{CH})$ & $196.7\left(\mathrm{CH}^{2}\right)$ \\
15 & $18.2\left(\mathrm{CH}_{3}\right)$ & $18.5\left(\mathrm{CH}_{3}\right)$ & $113.4\left(\mathrm{CH}_{2}\right)$ \\
16 & $172.1(\mathrm{C})$ & -- & -- \\
17 & $21.3\left(\mathrm{CH}_{3}\right)$ & -- & -- \\
\hline
\end{tabular}


Compound 3 was obtained as white amorphous powder, which gave a molecular formula of $\mathrm{C}_{15} \mathrm{H}_{22} \mathrm{O}_{2}$, as deduced by HRESIMS ( $\mathrm{m} / z$ 257.1510 [M+Na] $]^{+}$, calc. for $\mathrm{C}_{15} \mathrm{H}_{22} \mathrm{O}_{2} \mathrm{Na}$, 257.1517), indicating five degrees of unsaturation. The IR spectrum showed the presence of hydroxyl $\left(3433 \mathrm{~cm}^{-1}\right)$, $\alpha, \beta$-unsaturated aldehyde $\left(1682 \mathrm{~cm}^{-1}\right)$, and double-bond $\left(1631 \mathrm{~cm}^{-1}\right)$ absorptions.

Compound 3 could be assigned a similar structure to 2 by comparison of their ${ }^{1} \mathrm{H}-$ and ${ }^{13} \mathrm{C}-\mathrm{NMR}$ spectra (Tables 1 and 2). The major differences observed were the absence of the trisubstituted $\mathrm{C}=\mathrm{C}$ double bond between $\mathrm{C}-1$ and $\mathrm{C}-10$ present in 3 and the appearance of an exocyclic double bond between $\mathrm{C}-10\left(\delta_{\mathrm{C}} 149.0\right)$ and $\mathrm{C}-15\left(\delta_{\mathrm{C}} 113.4\right)$ and the oxygenated methine signal at $\delta_{\mathrm{C}} 68.5(\mathrm{C}-1)$ in 3. These were confirmed by the HMBC correlations from $\mathrm{H}-15\left(\delta_{\mathrm{H}} 5.07,5.12\right)$ to $\mathrm{C}-1, \mathrm{C}-9\left(\delta_{\mathrm{C}} 37.5\right)$, and $\mathrm{C}-10$. The other correlations in the HMBC and ${ }^{1} \mathrm{H}-{ }^{1} \mathrm{H}$ COSY spectra as shown in Figure 1 confirmed the connectivities in compound 3.

On the basis of the ROESY correlations (Figure 2), the relative configuration of $\mathbf{3}$ was determined to be the same as that of 2 , with $\mathrm{H}-1$ assigned as $\alpha$-oriented by the correlations of $\mathrm{H}-7 / \mathrm{H}-9 \mathrm{a}(\beta-\mathrm{H})$ and $\mathrm{H}-1 / \mathrm{H}-9 \mathrm{~b}(\alpha-\mathrm{H})$. The NOE correlations of $\mathrm{H}-3 \mathrm{a} / \mathrm{H}-5$ confirmed the $Z$-configuration of the double bond between $\mathrm{C}-4$ and $\mathrm{C}-5$. Thus, the structure of compound $\mathbf{3}$ (named heishuixiecaoline $\mathrm{C}$ ) was assigned as 6,7-dimethylmethylene-4-aldehyde-1 $\beta$-hydroxy-10(15)-ene-(4Z)-dicyclodecylene (Figure 3).

Known compounds were identified as volvalerenal C (4) [13], (+) pinoresinol-4,4'-di- $O-\beta$-Dglucopyranoside (5) [14], (+) pinoresinol-8- $O-\beta$-D-glucopyranoside (6) [15], 8-hydroxypinoresinol4,4'-di- $O$ - $\beta$-D-glucopyranoside (7) [16], (+) 8-hydroxypinoresinol-4'- $O$ - $\beta$-D-glucopyranoside (8) [14], (+) pinoresinol-4-O- $\beta$-D-glucopyranoside (9) [17], (+) 8-hydroxypinoresinol (10) [14], (+) 8hydroxypinoresinol-4- $O-\beta$-D-glucopyranoside (11) [14], patrinoside (12) [18], and kanokoside A (13) [19] by comparing their NMR spectroscopic data with the literature values. The structures of compounds 1-13 are shown in Figure 3.

Figure 3. Structures of compounds 1-13.
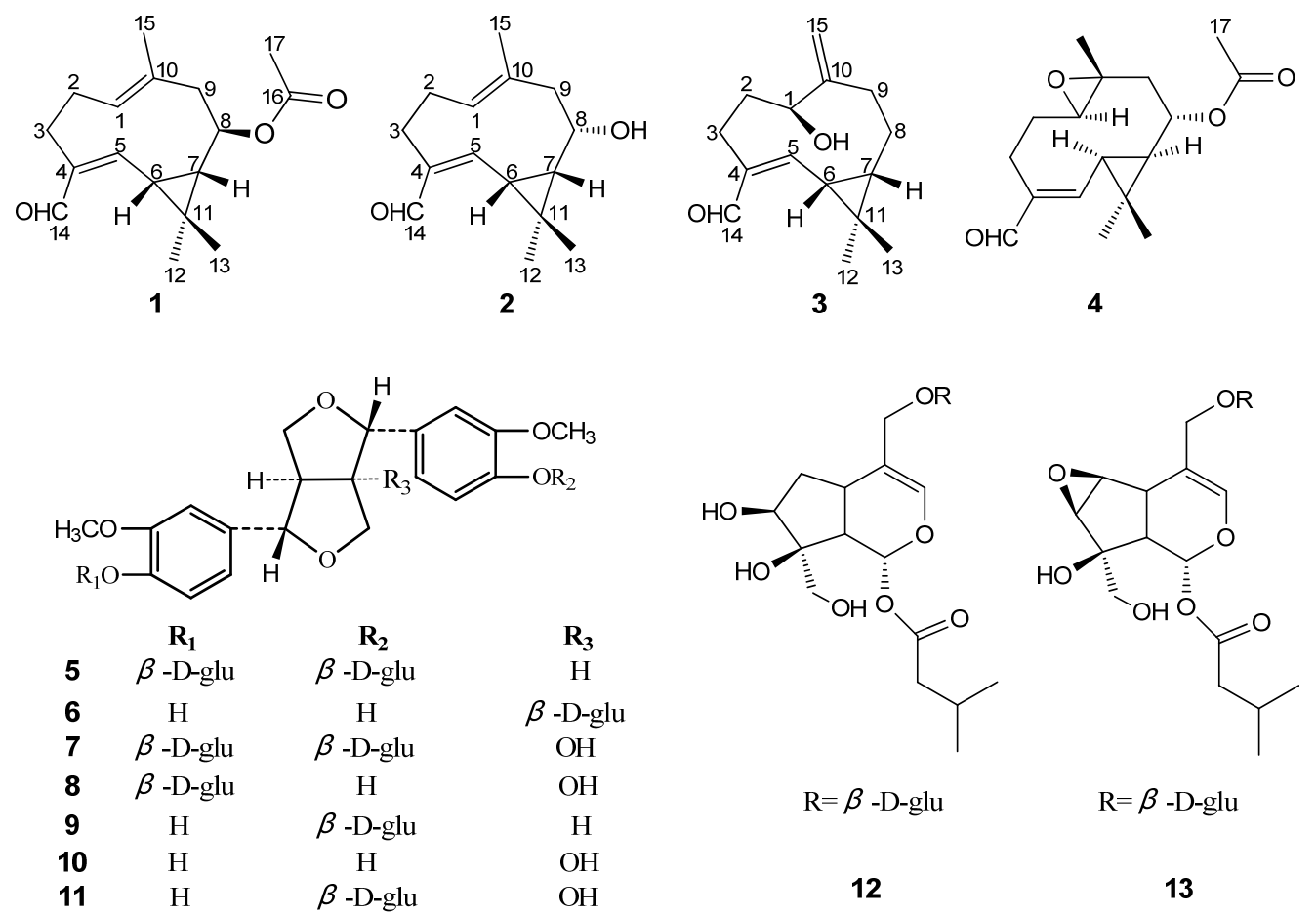

$\mathrm{OH}$

13 
The neuroprotective effects of compounds 1-13 against $\mathrm{A} \beta_{25-35}$ induced cell death in PC12 cells were assessed using an established MTT (3-(4,5-dimethylthiazol-2-yl)-2,5-diphenyl-2H-tetrazolium bromide) assay. $\mathrm{A} \beta_{25-35}$ induced cytotoxicity (56.94 $\pm 1.30 \%$ viability) in the cells when it was added at a concentration of $20 \mu \mathrm{M}$ for $24 \mathrm{~h}$. When PC12 cells were pre-incubated with vitamin $\mathrm{E}$ or compounds 1-15, the toxicity of $A \beta_{25-35}$ was significantly alleviated by vitamin $E$ and compounds 1-7 in a dose-dependent manner (Table 3). While compounds 8-13 showed negligible protective effects on the cell viability (data not shown).

Table 3. Neuroprotective effects of Compounds 1-7 against $\mathrm{A} \beta_{25-35}$-induced PC12 cells death.

\begin{tabular}{cccc}
\hline \multirow{2}{*}{ Compound } & \multicolumn{3}{c}{ Cell viability (\%) } \\
\cline { 2 - 4 } & $\mathbf{5} \boldsymbol{\mu} \mathbf{M}$ & $* * \mathbf{1 2} \boldsymbol{\mu M}$ & $* \mathbf{2 5} \boldsymbol{\mu M}$ \\
\hline $\mathbf{1}$ & $64.43 \pm 3.02$ & $69.77 \pm 2.45$ & $77.24 \pm 2.14$ \\
$\mathbf{2}$ & $65.16 \pm 4.20$ & $70.31 \pm 3.38$ & $78.33 \pm 3.29$ \\
$\mathbf{3}$ & $65.07 \pm 3.26$ & $72.97 \pm 3.47$ & $77.84 \pm 2.18$ \\
$\mathbf{4}$ & $64.85 \pm 4.14$ & $70.83 \pm 3.12$ & $80.38 \pm 4.46$ \\
$\mathbf{5}$ & $68.59 \pm 2.63$ & $75.81 \pm 4.79$ & $84.75 \pm 2.66$ \\
$\mathbf{6}$ & $71.52 \pm 3.34$ & $78.78 \pm 4.22$ & $89.54 \pm 3.27$ \\
$\mathbf{7}$ & $67.79 \pm 2.26$ & $75.80 \pm 2.19$ & $85.04 \pm 3.23$ \\
Vitamin E & $61.76 \pm 1.48$ & $70.47 \pm 2.56$ & $79.80 \pm 2.72$ \\
\hline
\end{tabular}

Effects of the tested compounds on A $\beta$-induced PC12 cell death. Cell viability was measured by MTT assay. Results are expressed as mean \pm SD $(n=8)$ of three independent experiments. The $100 \%$ value was obtained from untreated control cells. * Significant difference compared $25 \mu \mathrm{M}$ with 5 and $12 \mu \mathrm{M}$ of compounds 1-7 (* $p<0.01)$, respectively. ** Significant difference compared $12 \mu \mathrm{M}$ with 5 of compounds $1-7$ (** $p<0.05)$, respectively.

\section{Experimental}

\subsection{General}

The NMR spectra were recorded on a Bruker DPX 400 (400 MHz for ${ }^{1} \mathrm{H}-\mathrm{NMR}$ and $100 \mathrm{MHz}$ for ${ }^{13} \mathrm{C}-\mathrm{NMR}$, respectively, instrument (Bruker SpectroSpin, Karlsruhe, Germany). Chemical shifts are given as $\delta$ values with reference to tetramethylsilane (TMS) as an internal standard, and coupling constants are given in Hz. The HRESIMS analyses were conducted on Xero Q Tof MS spectrometer (Waters, Milford, MA, USA); Preparative HPLC was carried out on a Waters 600 instrument equipped with a Waters UV-2487 detector. A Waters Sunfire prep C18 OBD $(19 \times 250 \mathrm{~mm}$ i.d. $)$ column was used for preparative purpose. IR Spectra (Shimadzu FTIR-8400S, Kyoto, Japan); Anal. TLC (silica gel 60 F254, Merck, Darmstadt, Germany). Column chromatography (CC): silica gel (200-300 mesh, Haiyang Chemical Group Co. Ltd, Qingdao, China); ODS-A (120A, 50 mm; YMC, Kyoto, Japan). Macroporous absorption resin (AB-8 Crosslinked Polystyrene, Nan Kai, Tianjin, China) was employed for column chromatography. PC12 cells obtained from Institute of biochemistry and cell biology (Shanghai, China) were grown in Dulbecco's modified Eagle's medium (DMEM) (Hyclone, NRH0020), supplemented with 5\% fetal bovine serum and $1 \%$ antibiotic mixture comprising penicillin-streptomycin, in a humidified atmosphere at $37{ }^{\circ} \mathrm{C}$ with $5 \% \mathrm{CO}_{2}$. Microplate reader (Safire2, Tecan Group Ltd., Maennedorf, Switzerland) was used to determine the cell viability. 


\subsection{Plant Material}

The roots and rhizomes of $V$. amurensis were collected from the Great Xing'an Mountains area in 2010. The original plant was identified by Xiaowei Du of Heilongiiang University of Chinese Medicine. A voucher specimen (No. 20100806) was deposited at the Herbarium of Heilongjiang University of Chinese Medicine, China.

\subsection{Extraction and Isolation}

The dried roots and rhizomes of $V$. amurensis $(7.0 \mathrm{~kg}$ ) was extracted with $95 \% \mathrm{EtOH}(56 \mathrm{~L})$ for $2 \mathrm{~h} \times 3$ times under reflux conditions to give a residue $(578.2 \mathrm{~g})$ after removal of solvent under reduced pressure. The EtOH extract was suspended in $\mathrm{H}_{2} \mathrm{O}$ and then partitioned with petroleum ether $(5 \times 4 \mathrm{~L})$. The remaining water extract (450.6 g) was fractioned by AB-8 macroporous resin column $(10 \times 60 \mathrm{~cm})$ with $\mathrm{H}_{2} \mathrm{O}, 50 \%$ and $95 \% \mathrm{EtOH}$. The obtained $50 \% \mathrm{EtOH}$ fraction $(153.0 \mathrm{~g})$ possesses potential therapeutic effect towards AD. The 50\% EtOH fraction $(100.0 \mathrm{~g})$ was subjected to silica gel (200-300 mesh) column chromatography, eluted with $\mathrm{CHCl}_{3}-\mathrm{CH}_{3} \mathrm{OH}$ (from 50:1 to 1:1, v/v) to afford fractions I-VI. Fraction I (19.5 g) was subjected to column chromatography over silica gel, eluted with petroleum ether-EtOAc (from $40: 1$ to $1: 1, \mathrm{v} / \mathrm{v}$ ), to give six fractions, $\mathrm{I}_{1}-\mathrm{I}_{6}$. Fraction $\mathrm{I}_{3}\left(5.1 \mathrm{~g}\right.$ ) and $\mathrm{I}_{4}$ $(3.4 \mathrm{~g})$ was chromatographed over silica gel, eluted with petroleum ether-EtOAc (from 40:1 to 1:1, $\mathrm{v} / \mathrm{v})$, to afford fractions $\mathrm{I}_{3} \mathrm{a}-\mathrm{I}_{3} \mathrm{f}$ and $\mathrm{I}_{4} \mathrm{a}-\mathrm{I}_{4} \mathrm{f}$. Compound $1(25 \mathrm{mg})$ and $3(32 \mathrm{mg})$ were isolated from fraction $\mathrm{I}_{3} \mathrm{~b}$ by repeated column chromatography over silica gel, eluted with ether-EtOAc (from 40:1 to $15: 1, \mathrm{v} / \mathrm{v}$ ). Fraction $\mathrm{I}_{4}$ a was subjected to column chromatography over silica gel eluted with petroleum ether-EtOAc (from 20:1 to 5:1, v/v) to obtain Compound 2 (35 mg).

Heishuixiecaoline $A$ (1): white amorphous powder; $[\alpha]_{\mathrm{D}}^{20}+93.9(c 0.102, \mathrm{MeOH}) ; \mathrm{UV}(\mathrm{MeOH}) \lambda_{\max }$ $(\log \varepsilon) 257.5 \mathrm{~nm}$; IR (KBr): 1736, 1682, 1625, 1460, 1450, 1373, 1244, 1139, 1015 $\mathrm{cm}^{-1}$; ${ }^{1} \mathrm{H}-\mathrm{NMR}$ $\left(\mathrm{CD}_{3} \mathrm{OD}\right)$ and ${ }^{13} \mathrm{C}-\mathrm{NMR}\left(\mathrm{CD}_{3} \mathrm{OD}\right)$ data are shown in Tables 1 and 2; HRESIMS $\mathrm{m} / \mathrm{z} 299.1619$ $[\mathrm{M}+\mathrm{Na}]^{+}$(calcd for $\mathrm{C}_{17} \mathrm{H}_{24} \mathrm{O}_{3} \mathrm{Na}, 299.1623$ ).

Heishuixiecaoline B (2): white amorphous powder; $[\alpha]_{\mathrm{D}}^{20}+100.2(c 0.104, \mathrm{MeOH})$; UV (MeOH) $\lambda_{\max }$ ( $\log \varepsilon) 261 \mathrm{~nm}$; IR (KBr): 3429, 2938, 2813, 2706, 1689, 1624, 1452, 1370, 1184, $1002 \mathrm{~cm}^{-1}$; ${ }^{1} \mathrm{H}-\mathrm{NMR}$ $\left(\mathrm{CD}_{3} \mathrm{OD}\right)$ and ${ }^{13} \mathrm{C}-\mathrm{NMR}\left(\mathrm{CD}_{3} \mathrm{OD}\right)$ data are shown in Tables 1 and 2; HRESIMS $\mathrm{m} / \mathrm{z} 257.1514$ $[\mathrm{M}+\mathrm{Na}]^{+}$(calcd for $\mathrm{C}_{15} \mathrm{H}_{22} \mathrm{O}_{2} \mathrm{Na}, 257.1517$ ).

Heishuixiecaoline $C$ (3): white amorphous powder; $[\alpha]_{\mathrm{D}}^{20}-22.3$ (c $\left.0.112, \mathrm{MeOH}\right)$; UV (MeOH) $\lambda_{\max }$ $(\log \varepsilon) 266.9 \mathrm{~nm}$; IR (KBr): 3433, 1682, 1631, 1443, 1381, 1264, $1190 \mathrm{~cm}^{-1} ;{ }^{1} \mathrm{H}-\mathrm{NMR}\left(\mathrm{CD}_{3} \mathrm{OD}\right)$ and ${ }^{13} \mathrm{C}-\mathrm{NMR}\left(\mathrm{CD}_{3} \mathrm{OD}\right)$ data are shown in Tables 1 and 2; HRESIMS $m / z 257.1510[\mathrm{M}+\mathrm{Na}]^{+}$(calcd for $\left.\mathrm{C}_{15} \mathrm{H}_{22} \mathrm{O}_{2} \mathrm{Na}, 257.1517\right)$.

\subsection{Determination of Cell Viability}

Cell viability was measured by quantitative colorimetric assay with 3-(4,5-dimethylthiazol-2-yl)2,5-diphenyltetrazolium bromide (MTT) method as described previously [20]. Briefly, the cells were cultured at a density $5 \times 10^{4}$ cells per well in growth medium for $24 \mathrm{~h}$ in 96 -well plates, and then 
preincubated without or with various concentrations $(5,12,25 \mu \mathrm{M})$ of compounds $\mathbf{1}-\mathbf{1 3}$, which was followed $24 \mathrm{~h}$ later by exposure to $20 \mu \mathrm{M}$ aggregated $\mathrm{A} \beta_{25-35}$ (Sigma, St. Louis, MO, USA) prepared as described previously [21]. Vitamin E was used as a reference compound [22]. $25 \mu \mathrm{L} /$ well of MTT solution $(5 \mathrm{mg} / \mathrm{mL})$ was added and cells were incubated at $37{ }^{\circ} \mathrm{C}$ for $4 \mathrm{~h}$. Supernatants were then aspirated off and formazan crystals were dissolved with DMSO. The optical density of each well was determined at $490 \mathrm{~nm}$ using a microplate reader. Results were expressed as the percentages of reduced MTT, assuming the absorbance of control cells as $100 \%$. For comparing the results of MTT between the study groups, the $t$-test was used.

\section{Conclusions}

We investigated the chemical constituents of $V$. amurensis based on its activity towards AD for the first time and three new germacrane-type sesquiterpenoids were obtained. Their structures were identified as 10-methyl-6,7-dimethylmethylene-8 $\beta$-acetoxy-4-aldehyde-(4Z,10E)-dicyclodecadiene (1), 10 methyl-6,7-dimethylmethylene-8 $\alpha$-hydroxy-4-aldehyde-(4Z,10E))-dicyclodecadiene (2), and 6,7-dimethylmethylene-4-aldehyde-1 $\beta$-hydroxy-10(15)-ene-(4Z)-dicyclodecylene (3), respectively. Seven known cpompounds were also isolated and identified. All these compounds were screened and cell tests showed that germacrane-type sesquiterpenoids 1-4 and lignans 5-7 were the active components of Valeriana amurensis against AD.

\section{Acknowledgments}

This research was supported by the Program of International S\&T Cooperation of China (No. 2010DFA32440).

\section{References}

1. Huang, B.K.; Zheng, H.C.; Qin, L.P.; Zheng, Q.M.; Xin, H.L. Investigation on resource of genus Valeriana in China. J. Chin. Med. Mater. 2004, 27, 632-634.

2. Houghton, P.J. The biological activity of valerian and related plants. J. Ethnopharmacol. 1988, 22, 121-142.

3. Houghton, P.J. The scientific basis for the reputed activity of Valerian. J. Pharm. Pharmacol. 1999, 51, 505-512.

4. Yager, J.; Siegfreid, S.L.; DiMattero, T.L. Use of alternative remedies by psychiatric patients: Illustrative vignettes and a discussion of the issues. Am. J. Psychiatry 1999, 156, 1432-1438.

5. Bounthanh, C.; Bergmann, C.; Beck, J.P.; Haag-Berrurier, M.; Anton, R. Valepotrictes, a new class of cytotoxic and antitumor agents. Planta Med. 1981, 41, 21-28.

6. Tortarolo, M.; Braun, R.; Hübner, G.E.; Maurer, H.R. In vitro effects of epoxide-bearing valepotriates on mouse early hematopoietec progenitor cells and human T-lymphocytes. Arch. Toxicol. 1982, $51,37-42$.

7. Morazzoni, P.; Bombardelli, E. Valeriana officinalis: Traditional use and recent evaluation of activity. Fitoterapia 1995, 66, 99-112. 
8. Murakami, N.; Ye, Y.; Kawanishi, M.; Aoki, S.; Kudo, N.; Yoshida, M.; Nakayama, E.; Shiodac, T.; Kobayashi, M. New rev-transport inhibitor with anti-HIV activity from Valerianae Radix. Bioorg. Med. Chem. Lett. 2002, 12, 2807-2810.

9. Hattesohl, M.; Feistel, B.; Sievers, H.; Lehnfeld, R.; Hegger, M.; Winterhoff, H. Extracts of Valeriana officinalis L. s.l. show anxiolytic and antidepressant effects but neither sedative nor myorelaxant properties. Phytomedicine 2008, 15, 2-15.

10. Wu, J.K.; Huo, J.H.; Du, X.W. Pharmacological Effects of volatile oil of Valeriana amurensis on CNS. J. Chin. Med. Mater. 2007, 30, 977-980.

11. Zuo, Y.M.; Zhang, Z.L.; Wang, Q.H.; Xie, N.; Kuang, H.X. Effects of Valeriana amurensis on the expressions of $\beta$-APP, $A \beta_{1-40}$ and Caspase- 3 in Alzheimer's disease model rat's brain. J. Chin. Med. Mater. 2010, 33, 233-236.

12. Zhang, Z.L.; Zuo, Y.M.; Wang, Q.H.; Xiao, H.B.; Kuang, H.X. Effects of Valeriana amurensis on the expressions of iNOS, COX-2 and IкB- $\alpha$ in Alzheimer's disease model rat's brain. J. Chin. Med. Mater. 2010, 33, 581-583.

13. Wang, P.C.; Ran, X.H.; Chen, R.; Luo, H.R.; Liu, Y.Q.; Zhou, J.; Zhao, Y.X. Germacrane-type sesquiterpenoids from the roots of Valeriana officinalis var. latifolia. J. Nat. Prod. 2010, 73, $1563-1567$.

14. Britta, S.; Silke, S.; Josef, H.; Nasser, K.; Sonja, H.; Christa, M. Lignans Isolated from Valerian: Identification and Characterization of a New Olivil Derivative with Partial Agonistic Activity at A 1 Adenosine Receptors. J. Nat. Prod. 2002, 65, 1479-1485.

15. Wu, L.J. Natural Pharmaceutical Chemistry, 5th ed.; People's Medicinal Publishing House: Beijing, China, 2004; pp. 228-232.

16. Yu, D.Q.; Yang, J.S.; Handbook of Analytical Chemistry, 2nd ed.; Chemical Industry Press: Beijing, China, 2002; pp. 862-866.

17. Hu, X.J.; Jin, H.Z.; Su, J.; Zhang, W.; Xu, W.Z.; Yan, S.K.; Liu, R.H.; Lü, H.Z.; Zhang, W.D. Chemical Constituents from Daphne koreana Nakai. Chin. J. Nat. Med. 2008, 6, 411-414.

18. Tomassini, L.; Brkic, D.; Foddai, S.; Nicoletti, M. Iridoid glucosides from Viburnum rhytidophyllum. Phytochemistry 1997, 44, 751-753.

19. Ayse, K.U.; Zuhal Güvenalp, L.; Ömür, D.; Isabelle, B.; Karsten, S.; Axel, Z. 4'-Deoxy iridoid glycosides from Centranthus longiflorus. Phytochemistry 2002, 61, 937-941.

20. Hansen, M.B.; Nielsen, S.E.; Berg, K. Re-examination and further development of a precise and rapid dye method for measuring cell growth/cell kill. J. Immunol. Methods 1989, 119, 203-210.

21. Pike, C.J.; Burdick, D.; Walencewicz, A.J.; Glabe, C.G.; Cotman, C.W. Neurodegeneration induced by beta-amyloid peptides in vitro: the role of peptide assembly state. J. Neurosci. 1993, 13, 1676-1687.

22. Peng, Q.L.; Buz'Zard, A.R.; Lau, B.H. Pycnogenol protects neurons from amyloid-beta peptide-induced apoptosis. Brain Res. Mol. Brain Res. 2002, 104, 55-65.

Sample Availability: Samples of heishuixiecaoline A, B, and volvalerenal C are available from the authors.

(C) 2012 by the authors; licensee MDPI, Basel, Switzerland. This article is an open access article distributed under the terms and conditions of the Creative Commons Attribution license (http://creativecommons.org/licenses/by/3.0/). 